\title{
InSAR analysis for detecting the route of hydrothermal fluid to the surface during the 2015 phreatic eruption of Hakone Volcano, Japan
}

\author{
Ryosuke Doke ${ }^{1^{*}}\left(\mathbb{D}\right.$, Masatake Harada $^{1}$, Kazutaka Mannen ${ }^{1}$, Kazuhiro Itadera $^{1}$ and Jun Takenaka ${ }^{2}$
}

\begin{abstract}
Although the 2015 Hakone Volcano eruption was a small-scale phreatic eruption with a discharged mass of only about 100 tons, interferometric synthetic aperture radar successfully detected surface deformations related to the eruption. Inversion model of the underground hydrothermal system based on measured ground displacements by ALOS-2/PALSAR-2 images showed that a crack opened at an elevation of about 530-830 m, probably at the time of the eruption. A geomorphological analysis detected several old NW-SE trending fissures, and the open crack was located just beneath one of the fissures. Thus, the crack that opened during the 2015 eruption could have been a preexisting crack that formed during a more voluminous hydrothermal eruption. In addition, the inversion model implies that a sill deflation occurred at an elevation of about $225 \mathrm{~m}$, probably at the time of the eruption. The deflation of sill-like body represents a preexisting hydrothermal reservoir at an elevation of 100-400 m, which intruded fluid in the open crack prior to eruption. The volume changes of the open crack and the sill were calculated to be $1.14 \times 10^{5} \mathrm{~m}^{3}$ (inflation) and $0.49 \times 10^{5} \mathrm{~m}^{3}$ (deflation), respectively. A very local swelling (about $200 \mathrm{~m}$ in diameter) was also detected at the eruption center 2 months before the eruption. The local swelling, whose rate in satellite lineof-sight was $0.7-0.9 \mathrm{~cm} /$ day during May 2015 and declined in June, had been monitored until the time of the eruption, when its uplift halted. This was modeled as a point pressure source at an elevation of about $900 \mathrm{~m}$ (at a depth of about 80-90 $\mathrm{m}$ from the ground surface) and is considered to be a minor hydrothermal reservoir just beneath the fumarolic field. Our analysis shows that the northernmost tip of the open crack reached within $200 \mathrm{~m}$ of the surface. Thus, it is reasonable to assume that the hydrothermal fluid in the open crack found a way to the surface and formed the eruption.
\end{abstract}

Keywords: Phreatic eruption, Hakone Volcano, InSAR, ALOS-2/PALSAR-2, Open crack, Hydrothermal fluid

\section{Introduction}

Recent advances in interferometric synthetic aperture radar (InSAR) techniques have enabled us to perform high-resolution mapping of surface deformations caused by earthquakes and volcanic unrest. A set of InSAR images is transformed into a high-resolution surface displacement map in satellite line-of-sight without the

\footnotetext{
*Correspondence: r-doke@onken.odawara.kanagawa.jp

${ }^{1}$ Hot Springs Research Institute of Kanagawa Prefecture, 586 Iriuda,

Odawara, Kanagawa 250-0031, Japan

Full list of author information is available at the end of the article
}

help of observations on the ground or underground. For example, maps of surface displacements from the 2016 Kumamoto Earthquake gave detailed fault models that corresponded closely to the surface traces of local active faults (e.g., Ozawa et al. 2016; Himematsu and Furuya 2016). During the 2015 unrest of the Sakurajima Volcano, a dike intrusion was detected by InSAR images, and its volume change was estimated (Morishita et al. 2016).

Moreover, small-scale surface displacements can be detected in a wide range of observation areas from a set of InSAR images. In the case of the 2014 phreatic eruption of the Ontake Volcano in Japan, InSAR images detected 
surface displacements of about $10 \mathrm{~cm}$ toward a satellite in an area of about $1 \mathrm{~km}$ in diameter (Yamada et al. 2015). Detection of such narrow surface deformations during phreatic eruptions demonstrates the usefulness of InSAR analysis in volcano monitoring. Phreatic eruptions can cause damage to people and buildings because of ballistic fragments and toxic gas emissions. For example, the 2014 phreatic eruption of the Ontake Volcano, which discharged a mass of around $1.2 \times 10^{6}$ tons (Takarada et al. 2016), caused 58 fatalities and 5 missing persons.

This study focuses on the 2015 phreatic eruption of the Hakone Volcano in Japan, which occurred on June 29 to July 1,2015 . The discharged mass of the Hakone eruption was about ten-thousandth of that of the 2014 Ontake eruption, with no human injuries or deaths. However, the 2015 Hakone eruption is concerning from a risk management perspective, because many tourists visit near the site every day. Therefore, understanding the processes and the mechanisms of phreatic eruptions is important to prevent a possible disaster due to a similar future eruption.

The 2015 unrest of the Hakone Volcano was well observed by various instruments. In particular, the precise timing of the opening of a crack, which occurred at 7:32 a.m. (JST) on June 29 , was determined by tiltmeters and broadband seismometers (Honda et al. 2015). While InSAR does not have good time resolution due to satellite revisit time interval, it can provide high-resolution $(1 \sim 10 \mathrm{~m})$ displacement maps, allowing us to make a model of the crustal deformation that accompanied the eruption. Moreover, based on the precisely determined hypocenters during the 2009 Hakone unrest, Yukutake et al. (2011) demonstrated that swarm earthquakes were triggered by the diffusion of highly pressured fluids within a preexisting plane-like structure. Therefore, a better understanding of the hydrothermal system and shallow open cracks is considered essential to understand various phenomena observed at the volcanic activity of the Hakone Volcano. Here, we used InSAR to detect ground movements that occurred during the phreatic eruptions and develop a pressure source model to explain the observed crustal displacements. Model results help to explain shallow system processes of the Hakone Volcano before and after the phreatic eruption.

\section{Background}

Hakone is an andesitic caldera complex located approximately $100 \mathrm{~km}$ west of Tokyo (Fig. 1). Within the last 37,000 years, eruptive activity has formed a central cone of the volcano (Geological Society of Japan 2007). The latest magmatic eruption occurred about 3000 years ago on the northern slope of the central cone and caused a sector collapse that formed an amphitheater. Owakudani, the largest fumarole field of the volcano, is located at the eastern margin of the amphitheater (Fig. 1b). Based on geological investigations, Kobayashi et al. (2006) concluded that the most recent phreatic activity occurred in Owakudani during the twelfth to thirteenth century.

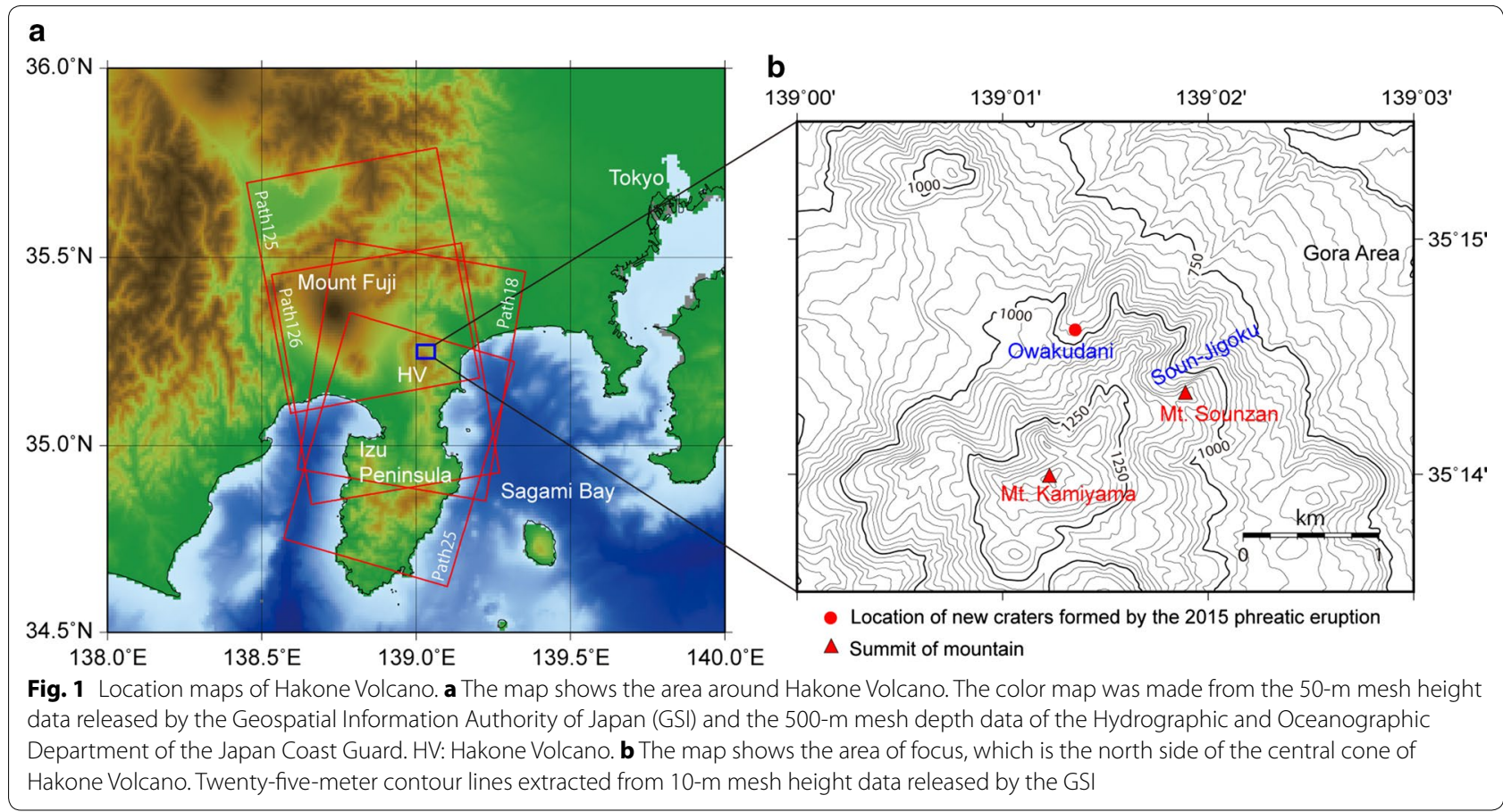


Earthquake swarm activities took place repeatedly in the Hakone Volcano after 2001. Measurements of recent swarm activity have been possible after the installation of modern geophysical instruments, with swarm events measured in 2001, 2006, 2008-2009, 2013, and 2015 (e.g., Harada et al. 2013; Itadera et al. 2015). The Global Navigation Satellite System (GNSS) detected 1-2 cm crustal deformations in about $20 \mathrm{~km} \mathrm{E-W}$ baseline containing whole mountains indicating inflation of the volcanic edifice during those swarm activities (e.g., Harada et al. 2016). In addition, tiltmeters detected formation of NW-SE trending open cracks in several hundred meters Northeast from Owakudani during the swarm events in 2001, 2013 (e.g., Daita et al. 2009; Miyaoka et al. 2013).

The 2015 earthquake swarm was the largest ever observed in the Hakone Volcano. More than 10,000 earthquakes were recorded beginning on April 26 and lasting through July (Fig. 2). GNSS observations detected about $2 \mathrm{~cm}$ of edifice inflation beginning in early April before the start of the swarm activities (Harada et al. 2015). Moreover, abnormal blowouts occurred on steam wells (facilities supplying hot spring waters) in Owakudani after May 3 (Mannen et al. 2015a). Surface displacements indicating a very local swelling around the steam wells were detected by InSAR analysis of images taken by Phased Array type L-band Synthetic Aperture Radar (PALSAR-2) on Advanced Land Observing Satellite 2 (ALOS-2), which was launched by the Japan Aerospace Exploration Agency (JAXA) (Fig. 3; Doke et al. 2015a; Yamada et al. 2016; Yarai et al. 2016). The rate of swelling was estimated $0.7-0.9 \mathrm{~cm} /$ day in satellite lineof-sight during May 2015 and declined in June (Doke et al. 2015a).

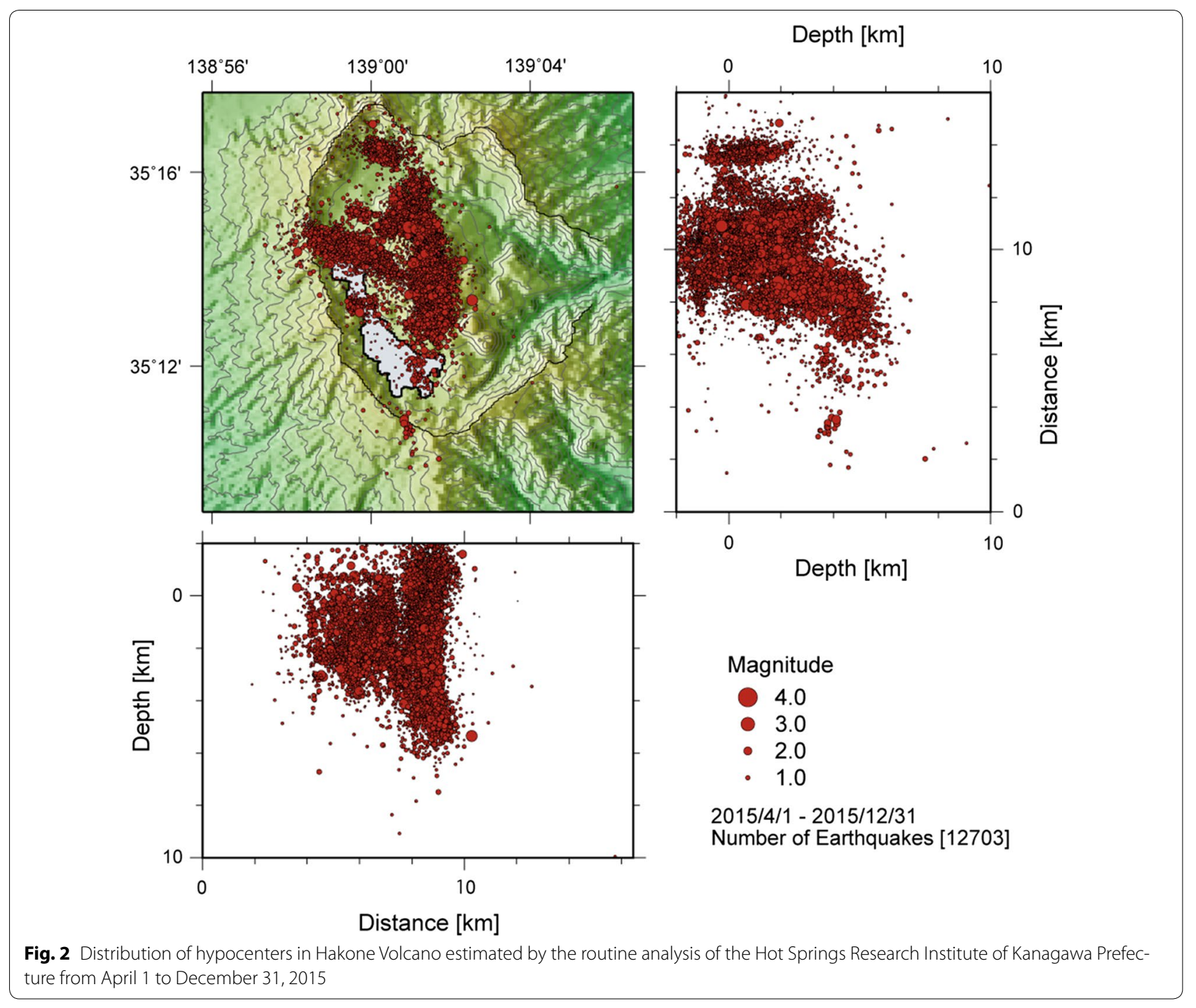


Although the swarm activity decreased toward the end of June, a phreatic eruption occurred on June 29 in Owakudani and lasted until July 1. During the eruption, seismic activity surged, and volcanic tremors were observed from 7:32 a.m. (JST) on June 29 for the first time (Suemine et al. 2015; Yukutake et al. 2017). Concurrently, tiltmeters and broadband seismometers observed tilt changes that implied the formation of NW-SE trending open cracks in several hundred meters Northeast from Owakudani that were probably caused by the intrusion of hydrothermal fluids (Honda et al. 2015). Moreover, rapid displacements implying a local swell in the Owakudani area were detected by ground-based SAR observation almost at the same time (Doke et al. 2015b). Mannen et al. (2015a) reported that volcanic ashfall started at around 0:30 p.m. (JST) on June 29. The total amount of ashfall was estimated to be $80-130$ tons (Furukawa et al. 2015). Intermittent volcanic tremors and infrasonic waves occurred from around 4:00 p.m. (JST) on June 29 to July 1 (Suemine et al. 2015; Yukutake et al. 2017). Four new craters and up to 20 fumaroles appeared during these activities (Mannen et al. 2015b).

\section{DInSAR data}

We investigated surface displacements during the 2015 phreatic eruption of the Hakone Volcano using the differential interferometric SAR (DInSAR) technique on ALOS-2/PALSAR-2 images. ALOS-2/PALSAR-2 observes surface displacements by multi-mode, rightand left-looking, multi-off nadir angles with a 14-day revisit interval. ALOS-2/PALSAR-2 observed the Hakone Volcano under five different orbits during the period of

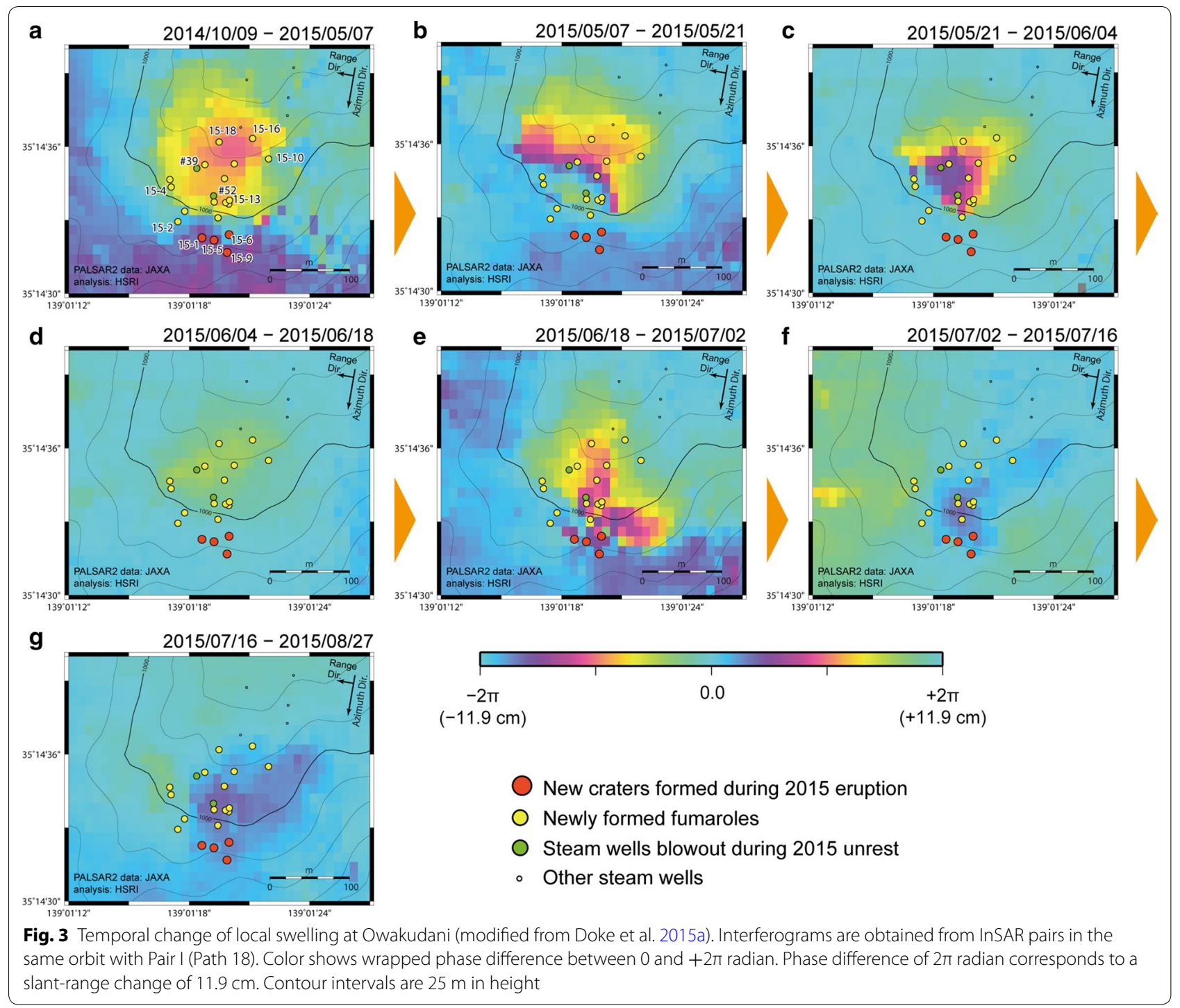


the 2015 unrest between May and September. For detecting short-term displacements, we analyzed four pairs of these ALOS-2/PALSAR-2 images (Table 1; Fig. 1a), which are the temporally nearest pairs before and after the eruption in each orbit, except for the orbit whose observation interval was 9 months. Two of the four pairs were used to make a source model of the open cracks, the first (Pair I) being the June 18/July 2, 2015 pair, which was acquired from a descending orbit with a perpendicular baseline of $314.5 \mathrm{~m}$ and a right-looking angle of about $42.8^{\circ}$ (Path 18). Pair I represents the image of short-term ground deformation before and after the eruption was captured from the east. The second (Pair II) is the June 7/ July 5 pair, which was acquired from an ascending orbit with a perpendicular baseline of $55.8 \mathrm{~m}$ and a right-looking angle of about $32.2^{\circ}$ (Path 125). Pair II represents the image captured from the west. Although other pairs captured from the west (Pairs III and IV) were also analyzed to understand the tendencies of the surface displacements, they were not used to make models, because additional surface displacements that did not accompany the phreatic eruption are included in the pairs due to these long observation intervals ( $>1$ month).

ALOS-2/PALSAR-2 images were processed using SARscape software (Sarmap). The images were averaged with $2 \times 2$ looks in azimuth and range (the output resolution of the interferogram is approximately $5 \mathrm{~m}$ ) to improve the signal-to-noise ratio. In the image processing, we used a dataset of ellipsoidal height that was generated from the 10-m mesh digital elevation model (DEM) released by the Geospatial Information Authority of Japan (GSI) and the earth gravitation model of 2008 (EGM2008) geoid model (Pavlis et al. 2012) to subtract the topographic contribution in the initial interferograms. Interferometric phase noise was reduced by applying an adaptive filter (Goldstein and Werner 1998), and DInSAR maps were unwrapped using the minimum cost flow approach (Costantini 1998) with a 0.2 coherence threshold. The effects of atmospheric delay were reduced by the phaseheight correlation method (e.g., Fujiwara et al. 1999). The images were geocoded to displacement maps with $5 \times 5 \mathrm{~m}$ meshes.
Figure 4 shows maps of slant-range displacement (i.e., one-dimensional displacement toward the satellite) spanning before and after the phreatic eruptions at the Owakudani area, with area of displacements discussed in the text labeled as Displacement areas A, B, and C. All maps show movement of the Owakudani area toward the satellite (Displacement area A), indicating local swelling beneath the steam wells. The swelling appears in interferograms from the very early dates (i.e., the first detection was by a pair between October 14, 2014, and May 7, 2015; Fig. 3a) and then is reactivated during the phreatic eruption (Fig. 3e; Doke et al. 2015a; Yamada et al. 2016; Yarai et al. 2016).

Pair I (Path 18) captured from the east shows that the ground around Mount Sounzan (Displacement area B) moved toward the satellite $(3-7 \mathrm{~cm})$, and the confined area between Mounts Kamiyama and Sounzan (Displacement area C) moved away from the satellite $(2-3 \mathrm{~cm}$; Fig. 4a). Other pairs (Paths 125, 126, and 25) captured from the west show that the area between Mounts Kamiyama and Sounzan (Displacement area C) moved away from the satellite $(3-6 \mathrm{~cm}$; Fig. 3b, c, d). Because the displacement patterns of Pair I in Displacement area B (Fig. 4a) differ from those of the other pairs, the eastward horizontal ground movement in Displacement area $B$ is thought to have been prominent. Although the time intervals of these displacement maps are different, common movements observed are as follows: The ground around Mount Sounzan moved to the east (Displacement area B), and the area between Mounts Kamiyama and Sounzan subsided (Displacement area C). We consider these displacements to be significant, because the same displacement pattern was also detected in the data captured under different orbits; however, it should be noted that atmospheric conditions and other noise might not have been the same.

\section{Modeling}

Previous studies on the change in tiltmeters implied the existence of NW-SE trending open crack sources of ground deformation (e.g., Daita et al. 2009). Shallow earthquake swarms are estimated to have been

Table 1 Interferometric pairs used in this study

\begin{tabular}{lcclllll}
\hline Pair & Path & Frame & Master date & Slave date & Orbit & Incident angle $\left(^{\circ}\right)$ & Perpendicular baseline $(\mathbf{m})$ \\
\hline I & 18 & 2910 & $2015 / 6 / 18$ & $2015 / 7 / 2$ & Descending, right & 42.8 & 314.5 \\
II & 125 & 700 & $2015 / 6 / 7$ & $2015 / 7 / 5$ & Ascending, right & 32.2 & 55.8 \\
III & $126^{\text {a }}$ & 690 & $2015 / 5 / 15$ & $2015 / 7 / 10$ & Ascending, right & 43.4 & 68.5 \\
IV & $25^{\text {a }}$ & 2910 & $2015 / 5 / 28$ & $2015 / 8 / 6$ & Descending, left & 45.5 & 304.9 \\
\hline
\end{tabular}

a Pairs III (Path 126) and IV (Path 25) were not used for the model inversion 


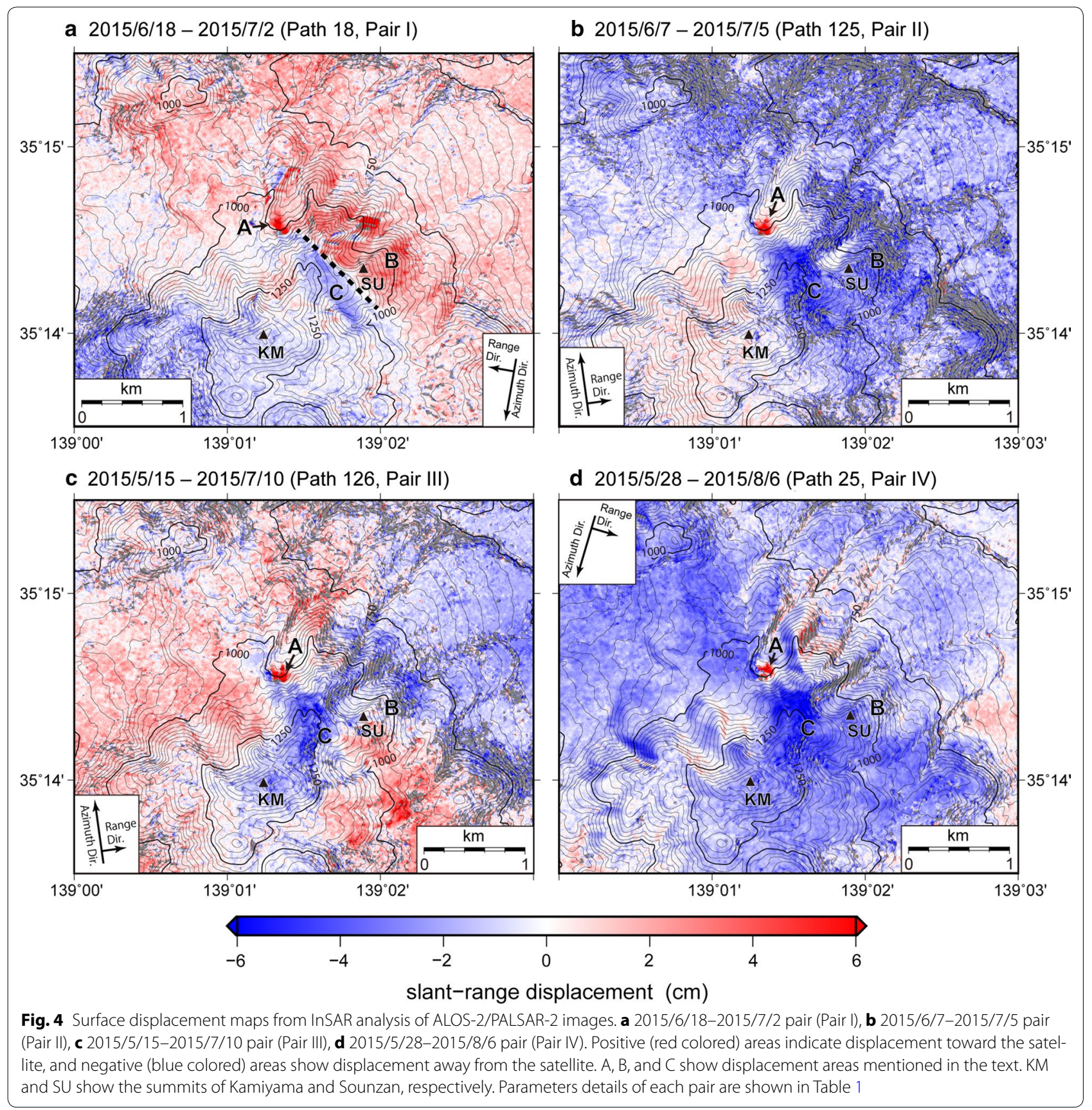

generated by the intrusion of hydrothermal fluids into preexisting plane-like structures (Yukutake et al. 2011). Consequently, we try to explain the ground deformation obtained by InSAR by the occurrence of the inflation of a preexisting open crack due to hydrothermal fluid intrusion from depth. In fact, displacements in areas B and C of Pair I are separated by a 1-km-long line in the NW-SE direction (dashed line in Fig. 4a). This displacement pattern and the eastward movement in Displacement area
$\mathrm{B}$ indicate the opening of a crack. Because the deformations are restricted spatially, we assume the measured displacements are not due to atmospheric factors and other noises. Even if the maps included atmospheric delay, the difference in displacements between $\mathrm{B}$ and $\mathrm{C}$ is still significant. Because no landslide of the scale corresponding to the deformation was observed during the 2015 unrest, it is reasonable to explain the displacements by an open crack. 
Two displacement maps (Pairs I and II) were subsampled with $50 \times 50 \mathrm{~m}$ meshes in a rectangular area, where the deformations were detected, and with $250 \times 250 \mathrm{~m}$ meshes in the surrounding area (Fig. 5). Less coherent pixels (coherences less than 0.5) were masked to reduce noise. In addition, the Owakudani area was excluded from the dataset because the displacement at that site showed a local swelling (Displacement area A), which should be modeled apart from an open crack. Figure 5 shows the subsampled datasets. We estimated open crack (tensile fault) models in an elastic and homogeneous half-space (Okada 1985) by using the modeling tools of SARscape software, which applied the nonlinear inversion algorithm on the basis of the Levenberg-Marquardt least-squares approach (Marquardt 1963). Additionally, the offset parameters for images were estimated in the modeling to assess the possible offset caused by longwave displacement or other noise that might affect the data. During the modeling, parameters of the altitude were given by the ellipsoidal height. Therefore, to convert altitudes to elevations in the following results and discussion, the geoid heights (about $40.5 \mathrm{~m}$ in the study area) were subtracted.

We first use the single open crack model to explain the ground displacement around Mount Sounzan, which moved toward the satellite in Pair I (Displacement area B). By carrying out a nonlinear inversion, we obtained optimum values for all eight parameters that determine the dimension and the disposition of the open crack (Table 2), with the volume change of the crack estimated at $1.56 \times 10^{5} \mathrm{~m}^{3}$. This model can explain the eastward movements in the northeast side of the open crack (Displacement area B; Fig. 6a, b). However, the ground movement in the area between Mounts Kamiyama and Sounzan (Displacement area $\mathrm{C}$ ) in the model is smaller than that in the observations (Fig. $5 \mathrm{c}, \mathrm{d}$ ). We thus consider that some other source of ground deformation is needed in addition to a single open crack, though the model generally explains the observed ground deformation.

Note that the existence of a deflation source is implied by Pair II (Fig. 4b) and the residuals between the single

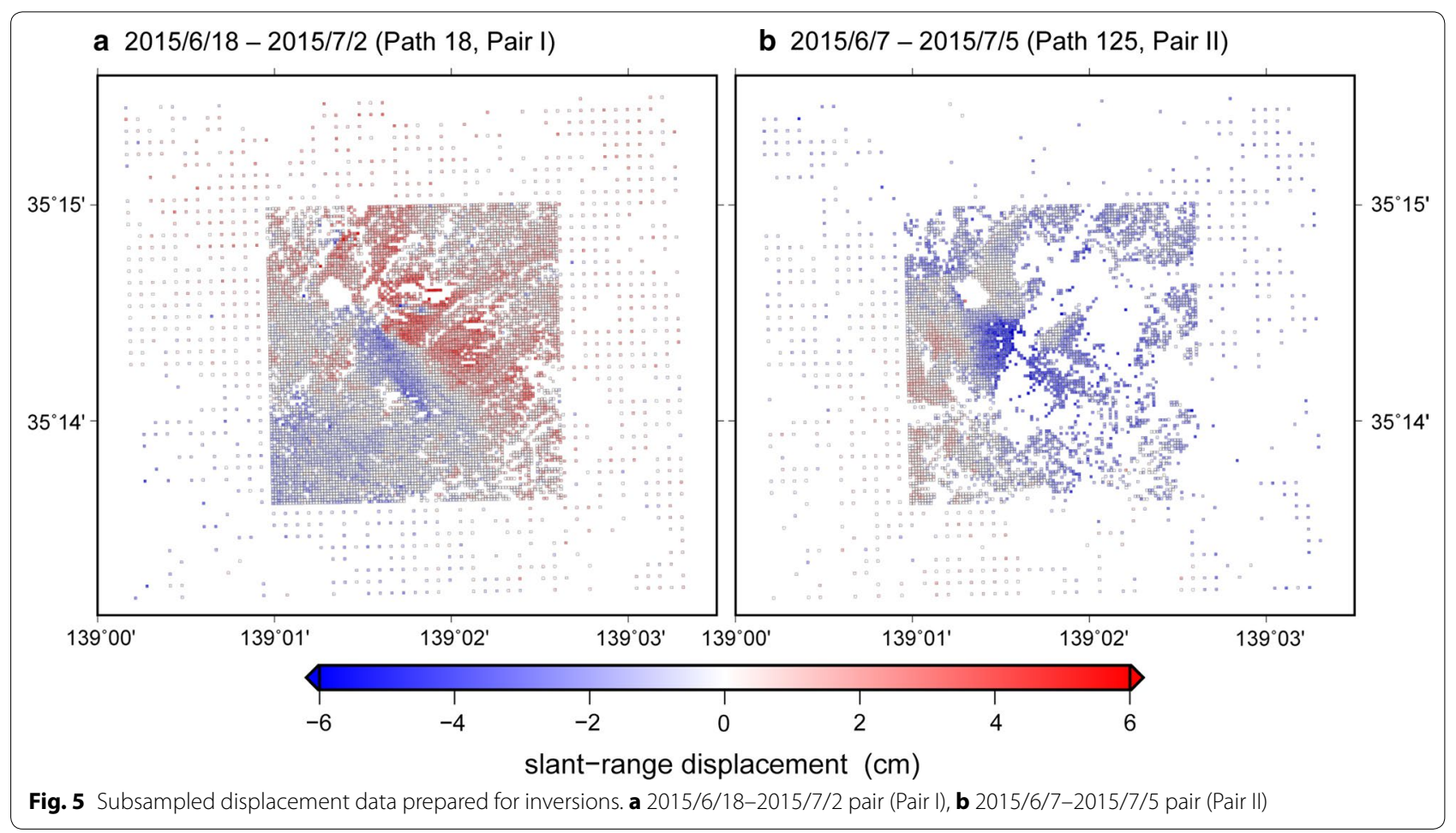

Table 2 Open crack parameters estimated from the first inversion (no reservoir at depth)

\begin{tabular}{llllllll}
\hline Length $(\mathrm{m})$ & Width $(\mathbf{m})$ & Altitude $^{\mathbf{a}}(\mathbf{m})$ & Strike $\left(^{\left.{ }^{\circ}\right)}\right.$ & Dip $^{\left({ }^{\circ}\right)}$ & East $^{\mathbf{b}}\left({ }^{\circ}\right)$ & North $^{\mathbf{b}}\left({ }^{\circ}\right)$ & Opening $^{(\mathbf{c m})}$ \\
\hline 1853.0 & 671.9 & $851.9(892.4)$ & 311.80 & 86.88 & 139.034072 & 35.233130 & 12.48 \\
\hline
\end{tabular}

altitude is height above sea level of the open crack top edge, with ellipsoidal height in parentheses

b East and North coordinates are in WGS84 and refer to the upper left corner of an open crack 


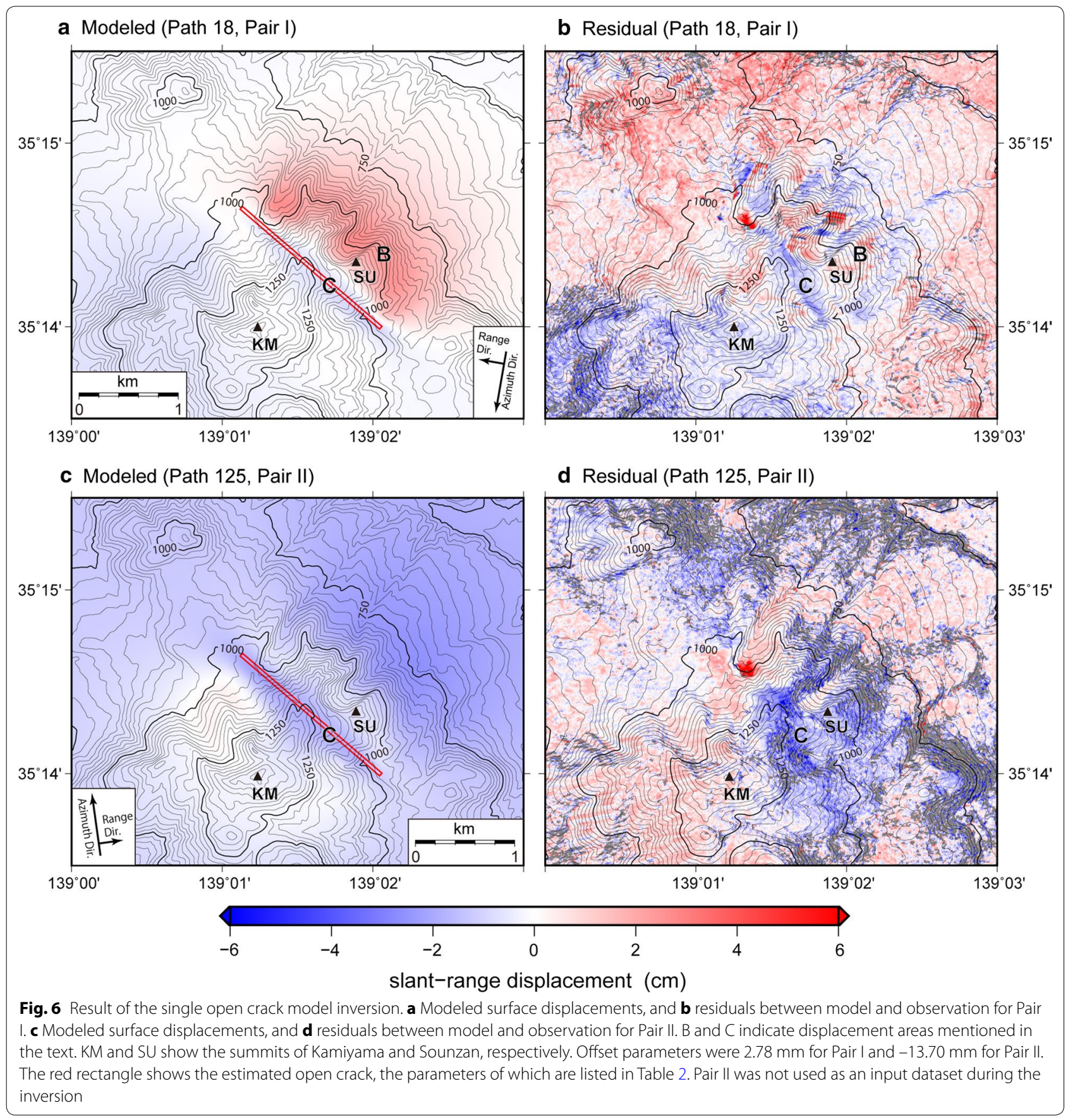

open crack model and observation (Fig. 6d). We see from these images that the area between Mounts Kamiyama and Sounzan moved away from the satellite (Displacement area $\mathrm{C}$ ). In the modeling, as a second model, we assumed two sources, an open crack and a deflation sill beneath the crack, and performed the inversion of Pairs I and II with all parameters free except for the dip of the sill (0 degrees). The optimum parameters of the two source models are summarized in Table 3. Volume changes of the open crack and sill were estimated at $1.14 \times 10^{5} \mathrm{~m}^{3}$ (inflation) and $0.49 \times 10^{5} \mathrm{~m}^{3}$ (deflation), respectively. This model better explains both Displacement areas B and C (Fig. 7).

In modeling the swell in Owakudani (Displacement area A), Pair I was subsampled with $10 \mathrm{~m} \times 10 \mathrm{~m}$ meshes in a rectangular area (Fig. 8a). We assumed a point pressure source in an elastic medium (Mogi 1958) beneath the Owakudani area and carried out the nonlinear 
Table 3 Open crack and sill (deflation source at depth) parameters estimated from the second inversion

\begin{tabular}{lllccccr}
\hline Length $(\mathbf{m})$ & Width $(\mathbf{m})$ & Altitude $^{\mathbf{a}}(\mathbf{m})$ & Strike $\left(^{\circ}\right)$ & Dip $^{\left({ }^{\circ}\right)}$ & East $^{\mathbf{b}}\left({ }^{\circ}\right)$ & North $^{\mathbf{b}}\left({ }^{\circ}\right)$ & Opening $^{(\mathbf{c m})}$ \\
\hline 1192.1 & 298.6 & $827.6(868.1)$ & 323.83 & 88.52 & 139.030707 & 35.233585 & 31.86 \\
261.4 & 304.1 & $224.9(265.4)$ & 0.00 & $0^{C}$ & 139.027414 & 35.235381 & -62.10 \\
\hline
\end{tabular}

${ }^{a}$ Altitudes are height above sea level of the crack top edges, with ellipsoidal heights in parentheses

${ }^{b}$ East and North coordinates are in WGS84 and refer to the upper left corner of cracks

c Parameter was fixed

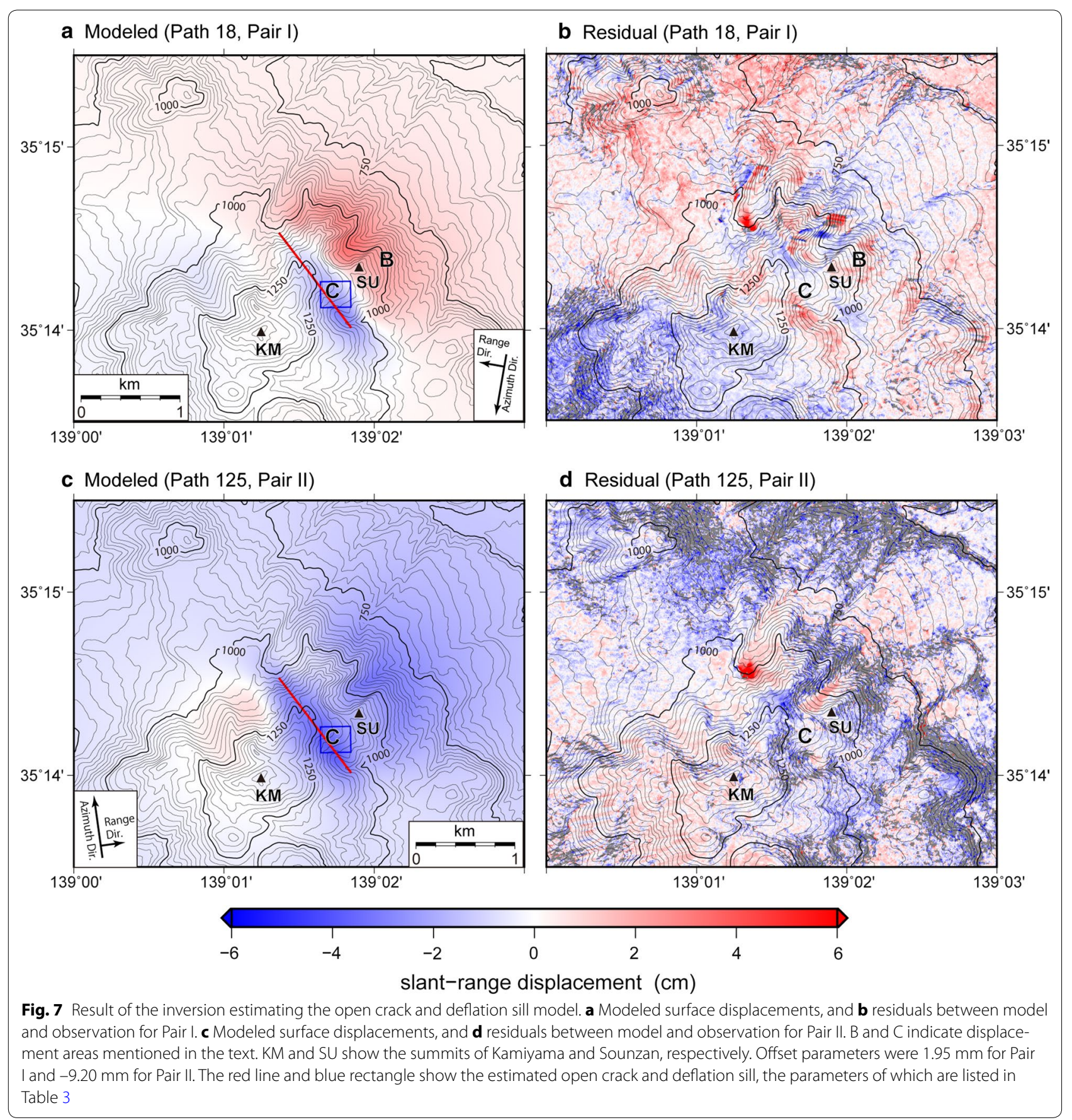


a Observed

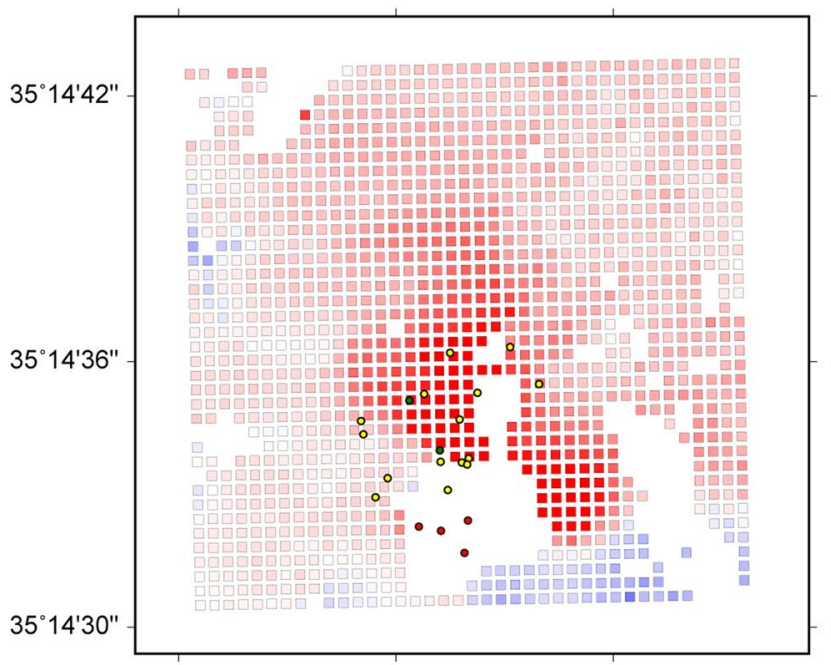

$139^{\circ} 01^{\prime} 12^{\prime \prime}$

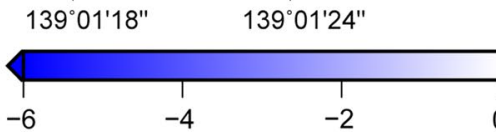

b Modeled

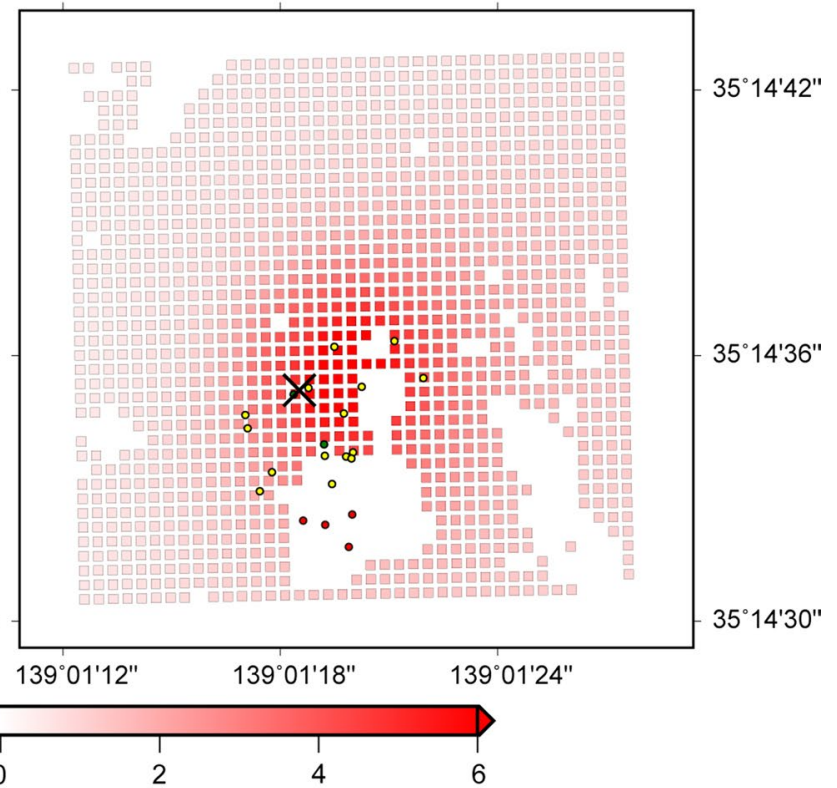

slant-range displacement $(\mathrm{cm})$

Fig. 8 Result of the inversion estimating the point pressure source beneath the Owakudani. a Subsampled displacement data of Pair I prepared for the inversion. b Modeled surface displacement. Offset parameter was $5.34 \mathrm{~mm}$. RMS of the residual between observation and model was $1.19 \mathrm{~cm}$ (RMS of the original dataset was $2.34 \mathrm{~cm}$ ). Green circles show the steam wells that experienced abnormal blowout during the 2015 unrest. Red and yellow circles show the newly formed craters and fumaroles, respectively. The "X" mark shows the location of the estimated point pressure source, the parameters of which are listed in Table 4

Table 4 Estimated parameters of point pressure source beneath the local swelling in Owakudani

\begin{tabular}{llll}
\hline Volume variation $\left(\mathbf{m}^{\mathbf{3}}\right)$ & Altitude $^{\mathbf{a}}(\mathbf{m})$ & East $^{\mathbf{b}}\left({ }^{\circ}\right)$ & North $^{\mathbf{b}}\left({ }^{\circ}\right)$ \\
\hline 2228.3 & $895.3(935.8)$ & 139.021813 & 35.243116 \\
\hline
\end{tabular}

a Altitude is height above sea level, with ellipsoidal height in parentheses

${ }^{b}$ East and North coordinates are in WGS84

inversion to estimate the optimum values for all four parameters that designated the source (Table 4; Fig. 8b). The depth of the estimated source is very shallow, only 80-90 $\mathrm{m}$ from the ground surface. Therefore, assuming an elastic medium to handle the modeling might be a problem. However, we consider that the result implies the existence of a very shallow inflation source beneath the swelling area in Owakudani.

\section{Discussion}

Relation between the estimated open crack and landforms Here, we quantitatively evaluate the two intrusion models: a single open crack and a combination of an open crack and a deflation sill. For each of the two models, the root mean square (RMS) of the residual between observed and modeled displacements at the subsampled points (Fig. 5) was calculated (Table 5). As shown in Table 5, the second model (combination of an open crack and a deflation sill) explains the ground movement better than the first one. In particular, the second model explains the subsidence in the area between Mounts Kamiyama and Sounzan (Displacement area C), which cannot be explained by the first model.

We would like to note here that the existence of several NW-SE trending fissures in the region where the open crack was estimated (Fig. 9; Kobayashi, 2008). This trend of the fissures coincides with the maximum horizontal stress in the caldera (Takahashi et al. 1999; Yukutake et al. 2006). Interestingly, the location of the open crack in the second model seems to correspond to fissures $g$ and $h$ in Fig. 9a. We think the similar locations of the modeled open crack with the fissures indicate that the crack is not a new one; that is, it was the reopening of a preexisting crack that once formed a fissure eruption in the past. The deflation sill in our second model might have been a reservoir of hydrothermal fluids that were injected into the open crack. 
Table 5 RMS of the residuals between observed and modeled displacements for the subsampled points

\begin{tabular}{llll}
\hline Dataset & $\begin{array}{l}\text { RMS (cm) } \\
\text { (single open crack) }\end{array}$ & $\begin{array}{l}\text { RMS (cm) } \\
\text { (open crack and sill) }\end{array}$ & $\begin{array}{l}\text { RMS (cm) } \\
\text { (Null Solution }{ }^{\text {a }}\end{array}$ \\
\hline $2015 / 6 / 18-2015 / 7 / 2$ (Pair I) & 0.95 & 0.94 & 1.33 \\
$2015 / 6 / 7-2015 / 7 / 5$ (Pair II) & $1.16^{b}$ & 0.92 & 1.73 \\
\hline
\end{tabular}

a The RMS of the null solution corresponds to the RMS of the data themselves

${ }^{b}$ The dataset was not used for the model inversion

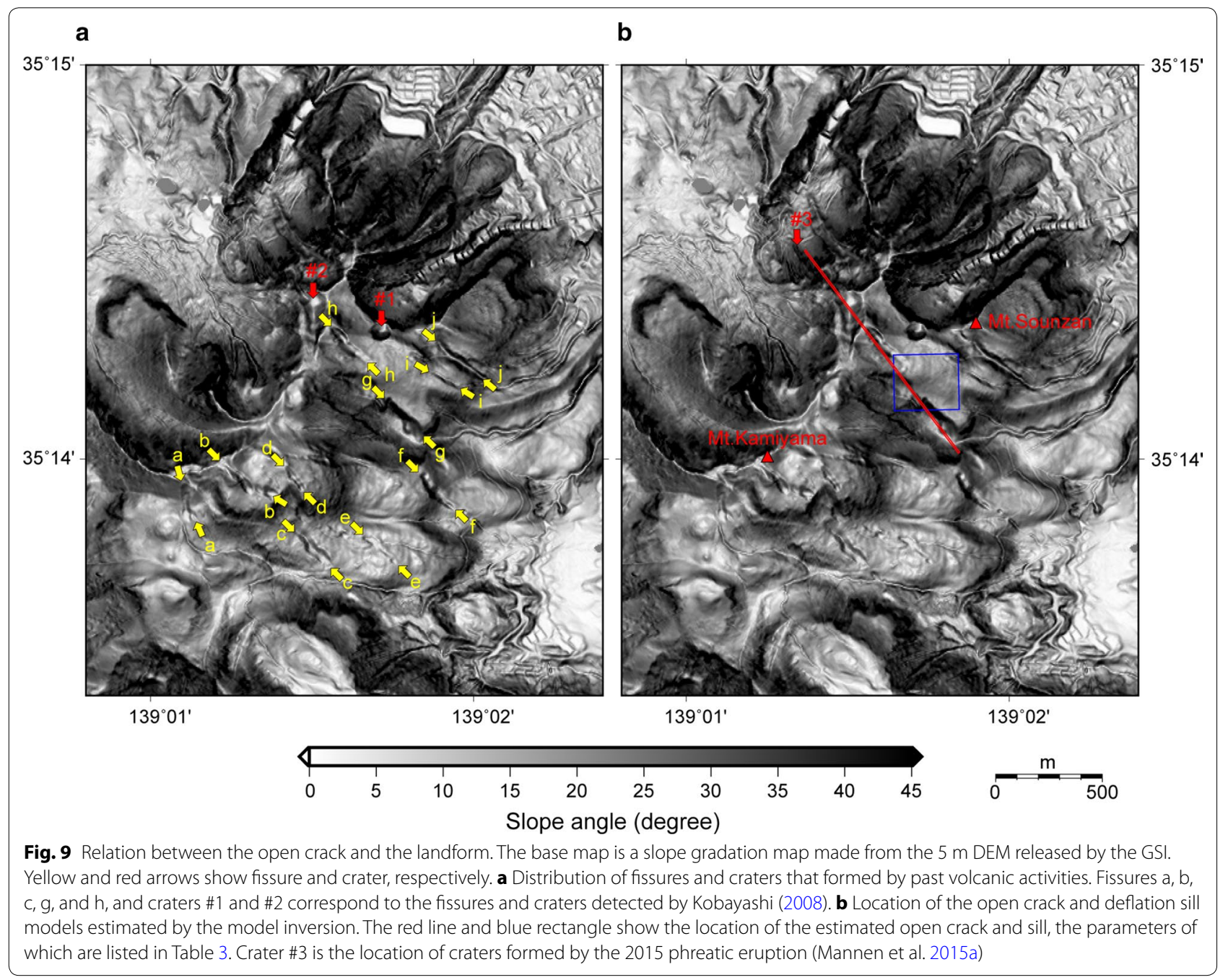

\section{Schematic model of hydrothermal intrusion during the 2015 phreatic eruption}

Our best-fit model for the hydrothermal system involved with the phreatic eruption is composed of an open crack elevation of about $530-830 \mathrm{~m}$, a deflation sill with an elevation of about $225 \mathrm{~m}$, and a very shallow source at Owakudani. Here, we give the geological background for these sources of geophysical deformation.
Located about $2 \mathrm{~km}$ northeast of the eruption center is the center of a major hot spring area named Gora, which has a diameter of 2-3 km (Fig. 1b). Geologically, this area forms subsidence or buried caldera structures created by ignimbrite-forming eruptions that occurred at 240 $60 \mathrm{ka}$ (Mannen 2014). Hot springs in the area are mainly formed from deep wells up to several hundred meters, and natural springs are limited to the eastern margin 

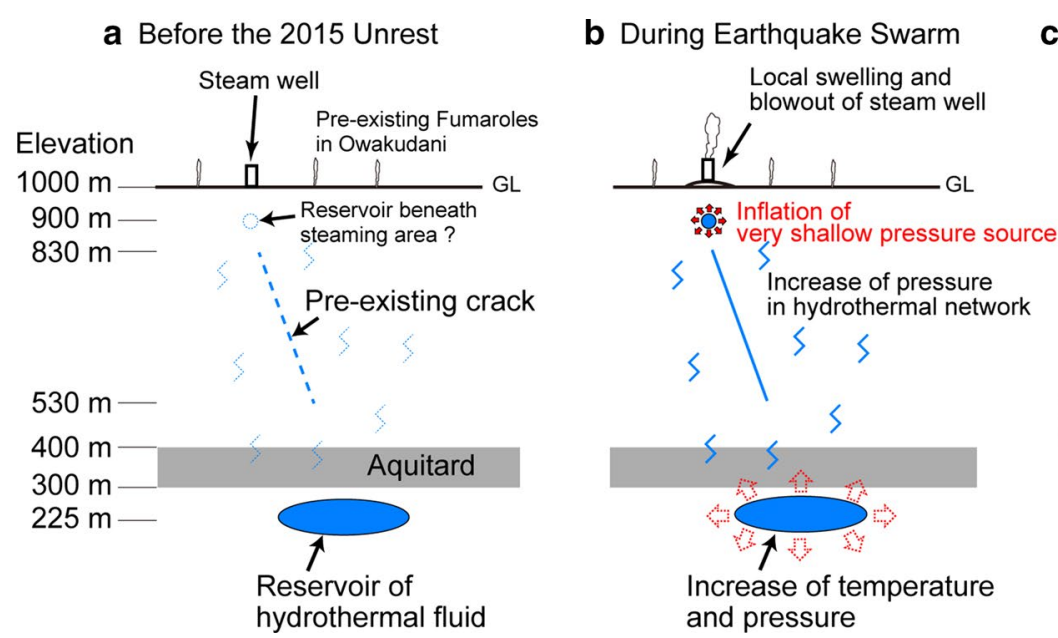

C Occurence of Phreatic Eruption

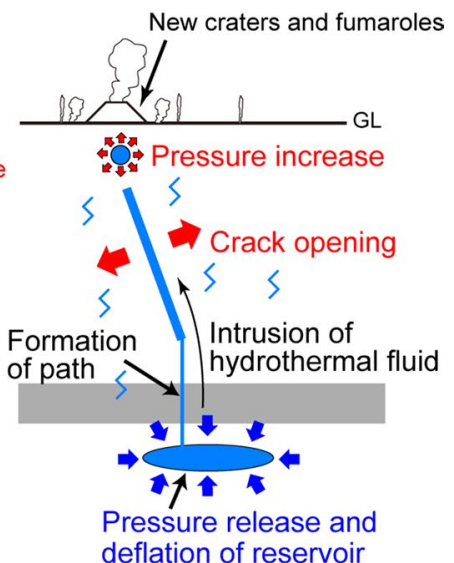

Fig. 10 Conceptual diagram of the 2015 volcanic activity of Hakone Volcano inferred from the data modeling of InSAR images. a The reservoir of hydrothermal fluid (elevation of about $225 \mathrm{~m}$ ) and the crack (elevation of 530-830 m) originally existed before the earthquake swarm.b Temperature and pressure possibly rose in the reservoir of hydrothermal fluid during the swarm activity, and an increase in pressure possibly occurred in the hydrothermal network. A small quantity of water or steam was uplifted to the ground surface and caused the very local swelling and the abnormal blowouts of steam wells. c When a path between the reservoir and crack formed, the hydrothermal fluid intruded from the reservoir to the crack.

The released pressure in the hydrothermal system caused inflation of a very shallow source located the northernmost part of the crack and resulted in the phreatic eruption

of the subsidence structure. From the geological analysis of these boreholes, it is known that a silty lacustrine deposit forms an aquitard at an elevation of 300-400 m in the subsidence structure. Below the aquitard is porous caldera-fill deposits composed of lapilli tuff that form an aquifer for waters characterized by high temperature $\left(>90{ }^{\circ} \mathrm{C}\right.$ ) and high $\mathrm{NaCl}$ content (Mannen 2014; Oki et al. 1968; Machida et al. 2007; Kikugawa et al. 2011). From the distribution of the water quality and the temperature of the hot springs in this region, Machida et al. (2007) concluded that the high-temperature and high- $\mathrm{NaCl}$ water seem to be upwelling from the deep source along a $1 \mathrm{~km}$ long, east-west trending dike-like crack in the center of the subsidence structure. This water is widely stored in the network of cracks at an elevation of 100$400 \mathrm{~m}$. Although no evidence of open crack formation appeared in the Gora region during the 2015 episode, the same but much smaller trending crack was known to be formed during the 2001 unrest (Daita et al. 2009). It is thus reasonable to consider that the hot springs in Gora form a part of the hydrothermal system connecting to a deep, perhaps near the magma chamber at about $10 \mathrm{~km}$ deep (Yukutake et al. 2015).

It is noteworthy that the elevation range of the hydrothermal system in Gora (100-400 m) includes the elevation of the deflation sill $(225 \mathrm{~m})$. Also noteworthy is the importance of the hydraulic head (or pressure loading on the water under an aquitard) of the hot springs in Gora, which are $400-600 \mathrm{~m}$ in elevation and higher in the southwest
(Oki et al. 1968; Machida et al. 2007), because the hydraulic head is close to that of the open crack in our second model (530-830 m). Because no deep well exists, we have no data on the geology and the hydraulic system at the area where the sill model was estimated. However, it is reasonable to assume a connection between the hydrothermal system in Gora and fumarole fields including Owakudani, Soun-Jigoku (Fig. 1b) and the area where the deflation sill was estimated, not only because of this proximity but also because of the hydraulic structure that shows a higher hydraulic head in these fumarole fields than Gora area.

The very shallow source modeled from the local swelling (Displacement area A) is located beneath the steam well, which is a blowout after May 3, 2015 (Mannen et al. 2015a). Moreover, the timing of the blowout almost corresponds to the start of local swelling, which was detected first in the InSAR pair of May 7 and older (Fig. 3a; Doke et al. 2015a; Yamada et al. 2016; Yarai et al. 2016). Therefore, the pressure source is considered as a shallow reservoir beneath the fumarole field.

Based on the discussion above, we modeled the migration of hydrothermal fluid during the eruption (Fig. 10). The principal reservoir of hydrothermal fluid in this region is located at an elevation of about $225 \mathrm{~m}$. This reservoir may be connected with fumarole fields such as Owakudani (Fig. 10a). The volcanic unrest characterized by earthquake swarm and blowouts of the steam wells were caused by pressurization of the total hydrothermal system; however, no significant migration of hydrothermal 
fluid took place because pressure loss in the narrow and probably complicated veins in the hydrothermal system was still strong (Fig. 10b). In the morning of June 29, the reservoir finally connected with the preexisting open crack and the migrated hydrothermal fluid increased the width of the crack to approximately $32 \mathrm{~cm}$ and decreased the thickness of the sill approximately $62 \mathrm{~cm}$ (Fig. 10c). It is noteworthy that the absolute volume changes of the open crack and the sill were of almost the same order $\left(1 \times 10^{5} \mathrm{~m}^{3}\right)$. This calculation also supports the migration model presented here, although the volume increase due to decompression caused by the migration to the shallow open crack may be inferred from the twice larger volume change of the open crack than that of the sill. It may be said that such a volume increase accelerated by the phase change in the preexisting open crack would have dramatically increased the pressure of the shallow underground source and resulted in the phreatic eruption.

\section{Conclusion}

We investigated surface displacements during the period before and after the 2015 phreatic eruption of the Hakone Volcano by using four pairs of ALOS-2/PALSAR-2 images. The obtained surface displacement maps show that the ground around Mount Sounzan moved to the east (Displacement area B) and the area between Mounts Kamiyama and Sounzan subsided (Displacement area C). Carrying out a nonlinear inversion based on the displacements obtained by two of the four pairs, we found that a combination model of an open crack and a deflation sill is better than a model of an open crack only. The estimated volume changes of the open crack and the sill were $1.14 \times 10^{5} \mathrm{~m}^{3}$ (inflation) and $0.49 \times 10^{5} \mathrm{~m}^{3}$ (deflation), respectively. In addition to the source model, a localized swelling detected in Owakudani (Displacement A) was also modeled as a point source. The very shallow pressure source is considered to be a reservoir of hot fluids beneath the fumarole field.

The location of the estimated open crack with the strike in the NW-SE direction coincides with the location of preexisting fissures that were probably formed during past volcanic activities. Elevation of the estimated deflation sill, at around $225 \mathrm{~m}$, is almost the same as the altitude of the supposed reservoir of hydrothermal fluids. Our models suggest that hydrothermal fluids stored in the reservoir (the sill at the elevation of about $225 \mathrm{~m}$ ) intruded into the preexisting fissures (elevation 530$830 \mathrm{~m}$ ) and reached the surface through the very shallow pressure source beneath Owakudani at the northernmost part of the crack causing the 2015 eruption.

There are some NW-SE trending fissures in the central cone of Hakone Volcano, which are similar to the open crack modeled in this study and associated with the horizontal stress. History of eruptions at these fissures should be made clear by the future geological study for assessing the eruption hazards.

\begin{abstract}
Abbreviations
ALOS-2: Advanced Land Observing Satellite 2; DEM: digital elevation model; DInSAR: differential interferometric SAR; EGM2008: earth gravitation model of 2008; GNSS: Global Navigation Satellite System; GSI: Geospatial Information Authority of Japan; InSAR: interferometric synthetic aperture radar; PALSAR-2: Phased Array type L-band Synthetic Aperture Radar; JAXA: Japan Aerospace Exploration Agency; RMS: root mean square.
\end{abstract}

\section{Authors' contributions}

RD performed the InSAR analysis and modeling. He also wrote the manuscript. KM found the deformation due to the open crack in InSAR images and assisted in the interpretation with MH and JT. KI discussed the hydrothermal system of Hakone Volcano. All authors read and approved the final manuscript

\section{Author details}

${ }^{1}$ Hot Springs Research Institute of Kanagawa Prefecture, 586 Iriuda, Odawara, Kanagawa 250-0031, Japan. ${ }^{2}$ Japan Meteorological Agency, 1-3-4 Otemachi, Chiyoda-ku, Tokyo 100-8122, Japan.

\section{Acknowledgements}

We would like to thank Akio Yoshida, Mikio Satomura, Ryou Honda, and Yohei Yukutake for their useful discussions and comments about the interpretation of our results. We thank two anonymous reviewers for their constructive comments to improve our manuscript. ALOS-2/PALSAR-2 data were provided by JAXA via the Coordinating Committee for the Prediction of Volcanic Eruption as part of the project "ALOS Domestic Demonstration on Disaster Management Application" of the Volcano Working Group. The original ALOS-2/PALSAR-2 data belong to JAXA. We used the Generic Mapping Tools (Wessel and Smith 1998) for drawing the figures.

\section{Competing interests}

The authors declare that they have no competing interests.

\section{Availability of data and materials}

The data that support the findings of this study were provided by JAXA. The original data belong to JAXA.

\section{Consent for publication}

Not applicable.

Ethics approval and consent to participate

Not applicable.

Funding

This work was supported by MEXT "Integrated Program for NEXT Generation Volcano Research and Human Resource Development."

\section{Publisher's Note}

Springer Nature remains neutral with regard to jurisdictional claims in published maps and institutional affiliations.

Received: 4 October 2017 Accepted: 5 April 2018

Published online: 18 April 2018

\section{References}

Costantini M (1998) A novel phase unwrapping method based on network programming. IEEE Trans Geosci Remote Sens 36:813-821. https://doi. org/10.1109/36.673674

Daita Y, Tanada T, Tanbo T, Ito H, Harada M, Mannen K (2009) Temporal change of the pressure source estimated by tilt records during the 2001 
Hakone swarm activity. Bull Volcanol Soc Jpn 54:223-234. https://doi. org/10.18940/kazan.54.5_223 (in Japanese with English abstract)

Doke R, Harada M, Takenaka J (2015a) InSAR analysis of surface displacements in Owakudani associated with the 2015 Hakone volcanic activity. Bull Hot Springs Res Inst Kanagawa Prefect 47:23-29 (in Japanese)

Doke R, Harada M, Takenaka J, Mannen K (2015b) Surface deformation at Owakudani associated with 2015 volcanic activities of Hakone Volcano. Programme and abstracts of the Volcanological Society of Japan 2015 fall meeting: A3-13. https://doi.org/10.18940/vsj.2015.0_41 (in Japanese)

Fujiwara S, Tobita M, Murakami M, Nakagawa H, Rosen PA (1999) Baseline determination and correction of atmospheric delay induced by topography of SAR interferometry for precise surface change detection. J Geod Soc Jpn 45:315-325. https://doi.org/10.11366/sokuchi1954.45.315 (in Japanese with English abstract)

Furukawa R, Ishizuka Y, Yamasaki S, Mannen K, Nagai M, Miwa T, Yoshimoto M, Tsunematsu K, Uchiyama T, Baba A (2015) Pyroclastic fall deposit of 2015 eruption from Hakone Volcano, Japan. Programme and abstracts of the Volcanological Society of Japan 2015 fall meeting: P39. https://doi. org/10.18940/vsj.2015.0_191 (in Japanese)

Geological Society of Japan (2007) Geological leaflet 1 Hakone Volcano. Geological Society of Japan (in Japanese)

Goldstein RM, Werner CL (1998) Radar interferogram filtering for geophysical applications. Geophys Res Lett 25:4035-4038. https://doi. org/10.1029/1998GL900033

Harada M, Yukutake Y, Miyaoka K, Honda R, Itadera K, Doke R, Satomura M, Yoshida A (2013) The classification of earthquake swarm activities in Hakone Volcano. Bull Hot Springs Res Inst Kanagawa Prefect 45:1-8 (in Japanese with English abstract)

Harada M, Itadera K, Honda R, Yukutake Y, Doke R (2015) Earthquake swarm activities and crustal movement of the 2015 volcanic event at Hakone Volcano (Rapid results). Bull Hot Springs Res Inst Kanagawa Prefect 47:1-10 (in Japanese with English abstract)

Harada M, Doke R, Itadera K, Satomura M (2016) GNSS crustal movement observed by volcanic activities of Hakone Volcano and estimated its pressure sources. Programme and abstracts the Seismological Society of Japan 2016, fall meeting: S03-P14 (in Japanese)

Himematsu Y, Furuya M (2016) Fault source model for the 2016 Kumamoto earthquake sequence based on ALOS-2/PALSAR-2 pixel-offset data: evidence for dynamic slip partitioning. Earth Planets Space 68:169. https:// doi.org/10.1186/s40623-016-0545-7

Honda R, Yukutake Y, Harada M, Kato K, Uhira K, Morita Y, Sakai S (2015) Tilt changes and volcanic tremor observed prior to a small eruption of Hakone in 29 June, 2015. Programme and abstracts, of the Volcanological Society of Japan 2015 fall meeting: P48. https://doi.org/10.18940/vsj.2015.0_146 (in Japanese)

Itadera K, Honda R, Harada M, Yukutake Y, Doke R, Takenaka J (2015) Earthquake swarm activity in Hakone Volcano in 2015. J Jpn Assoc Hydrol Sci 45:47-49. https://doi.org/10.4145/jahs.45.47 (in Japanese)

Kikugawa G, Itadera K, Yoshida A (2011) A new classification of hot spring waters welling out in the Gora Buried Caldera Structure, Hakone, Japan. J Hot Spring Sci 60:445-458 (in Japanese with English abstract)

Kobayashi M (2008) Eruption history of Hakone Central Cone Volcanoes, and geographical development closely related to eruptive activity in Hakone Caldera. Res Rep Kanagawa Prefect Mus Nat Hist 13:43-60 (in Japanese with English abstract)

Kobayashi M, Mannen K, Okuno M, Nakamura T, Hakamata K (2006) The Owakidani tephra group: a newly discovered post-magmatic eruption product of Hakone Volcano, Japan. Bull Volcanol Soc Jpn 51:245-256. https://doi. org/10.18940/kazan.51.4_245 (in Japanese with English abstract)

Machida I, Itadera K, Mannen K (2007) Source area of heat and NaCl for hot springs in Gora region, Hakone. J Groundw Hydrol 49:327-339. https:// doi.org/10.5917/jagh1987.49.327

Mannen K (2014) Post-caldera geology of Gora Region in Hakone Volcano Group, Japan. J Geol Soc Jpn 120:117-136. https://doi.org/10.5575/geosoc.2014.0007 (in Japanese with English abstract)

Mannen K, Doke R, Harada M, Honda R, Itadera K, Kikugawa G, Yukutake Y, Takenaka J (2015a) Chronology of the 2015 eruption of Hakone Volcano, Japan. Programme and abstracts of the Volcanological Society of Japan 2015 fall meeting: A3-12. https://doi.org/10.18940/vsj.2015.0_40 (in Japanese)

Mannen K, Kikugawa G, Honda R, Harada M, Nagai M, Miwa T, Furukawa R, Ishizuka Y, Yamasaki S, Yoshimoto M, Tsunematsu K, Uchiyama T, Baba A, Suzuki Y, Matsushima T, Sakai S, Morita Y (2015b) Eruptive vents formed during the 2015 eruption of Hakone Volcano, Japan; their formation, collapse and activity. Programme and abstracts of the Volcanological Society of Japan 2015 fall meeting: P90. https://doi.org/10.18940/vsj.2015.0_188 (in Japanese)

Marquardt DW (1963) An algorithm for least-squares estimation of nonlinear parameters. J Soc Ind Appl Math 11:431-441. https://doi. org/10.1137/0111030

Miyaoka K, Harada M, Honda R, Yukutake Y (2013) Crustal deformation according to earthquake swarm activities and estimation of the volcanic deformation source at Hakone. Abstracts, Japan Geoscience Union meeting 2013: SVC48-P25

Mogi K (1958) Relations between the eruptions of various volcanoes and the deformations of the ground surfaces around them. Bull Earthq Res Inst 36:99-134

Morishita Y, Kobayashi T, Yarai H (2016) Three-dimensional deformation mapping of a dike intrusion event in Sakurajima in 2015 by exploiting the right- and left-looking ALOS-2 InSAR. Geophys Res Lett 43:4197-4204. https://doi.org/10.1002/2016GL068293

Okada Y (1985) Surface deformation due to shear and tensile faults in a halfspace. Bull Seismol Soc Am 75:1135-1154

Oki Y, Ogino K, Hirano T, Hirota S, Ohguchi T, Moriya M (1968) Anomalous temperature encountered in the Gora hydrothermal system of Hakone Volcano and its hydrological explanation. Bull Hot Springs Res Inst Kanagawa Prefect 1(6):1-20 (in Japanese with English abstract)

Ozawa T, Fujita E, Ueda H (2016) Crustal deformation associated with the 2016 Kumamoto Earthquake and its effect on the magma system of Aso volcano. Earth Planets Space 68:186. https://doi.org/10.1186/ s40623-016-0563-5

Pavlis NK, Holmes SA, Kenyon SC, Factor JK (2012) The development and evaluation of the Earth Gravitational Model 2008 (EGM2008). J Geophys Res Solid Earth. https://doi.org/10.1029/2011jb008916

Suemine K, Wada S, Ikeda K, Nakamura M (2015) The volcanic activity in and around Hakoneyama-Owakudani in 2015. Programme and abstracts, of the Volcanological Society of Japan 2015 fall meeting: P91. https://doi. org/10.18940/vsj.2015.0_189 (in Japanese)

Takahashi M, Nagai M, Naito S, Nakamura N (1999) Formation history in Hakone Volcano and regional tectonic field. Chikyu Monthly 21:437-445 (in Japanese)

Takarada S, Oikawa T, Furukawa R, Hoshizumi H, Ji Itoh, Geshi N, Miyagi I (2016) Estimation of total discharged mass from the phreatic eruption of Ontake Volcano, central Japan, on September 27, 2014. Earth, Planets and Space 68(1):138. https://doi.org/10.1186/s40623-016-0511-4

Wessel P, Smith WHF (1998) New improved version of generic mapping tools released. EOS Trans AGU 79(47):579. https://doi.org/10.1029/98EO00426

Yamada S, Morishita Y, Wada K, Kikkawa T, Yamanaka M, Fujiwara S, Tobita M, Yarai H, Kobayashi T (2015) Detection of deformation triggered by eruption of Mt. Ontake Volcano with InSAR using ALOS-2 data. J Geospat Inf Auth Jpn 127:11-15 (in Japanese)

Yamada S, Miura Y, Yamanaka M, Nakai H, Wada K, Kakiage Y, Ueshima H, Yarai H, Kobayashi T, Morishita Y (2016) Ground surface deformation at Owakudani on Hakone Volcano detected with InSAR using ALOS-2 data. $J$ Geospat Inf Auth Jpn 128:67-75 (in Japanese)

Yarai H, Kobayashi T, Morishita Y, Yamada S, Miura Y, Wada K, Nakai H, Yamanaka M, Kakiage Y, Ueshiba H (2016) Active volcano monitoring using ALOS-2 SAR interferometry. J Japan Soc Photogramm Remote Sens 55:6-11. https://doi.org/10.4287/jsprs.55.6 (in Japanese)

Yukutake Y, Tanada T, Honda R, Ito H, Harada M (2006) The determination of focal mechanisms in the region of western Kanagawa. Bull Hot Springs Res Inst Kanagawa Prefect 38:69-76 (in Japanese)

Yukutake Y, Ito H, Honda R, Harada M, Tanada T, Yoshida A (2011) Fluid-induced swarm earthquake sequence revealed by precisely determined hypocenters and focal mechanisms in the 2009 activity at Hakone Volcano, Japan. J Geophys Res 116:B04308. https://doi.org/10.1029/2010JB008036

Yukutake Y, Honda R, Harada M, Arai R, Matsubara M (2015) A magma-hydrothermal system beneath Hakone Volcano, central Japan, revealed by highly resolved velocity structures. J Geophys Res Solid Earth 120:32933308. https://doi.org/10.1002/2014JB011856

Yukutake Y, Honda R, Harada M, Doke R, Saito T, Ueno T, Sakai S, Morita Y (2017) Analyzing the continuous volcanic tremors detected during the 2015 phreatic eruption of the Hakone Volcano. Earth Planets Space. https://doi. org/10.1186/s40623-017-0751-y 